\title{
Language Teaching in Turbulent Times: Curriculum-Savvy Teachers for Curriculum Success and Sustainability
}

\author{
Mohamed Daoud, Institut Supérieur des Langues de Tunis
}

\section{Introduction}

Nobody doubts the ever-growing need for English as a global language and for improving ELT research and practice. A suitable level of competence in English is ever more valued in the Middle East and North Africa (MENA) region, and particularly in Arabic/French-speaking North Africa, including Tunisia in the post-2011 revolution era, in a turbulent environment marked by socio-economic problems, high youth unemployment, migration, terrorism and armed conflict. Yet, overall competence in English has remained low in spite of decades of language instruction. This situation requires us as applied linguists, yet again, to revisit our assumptions about language, language teaching and learning, curriculum design and language-in-education policy and planning.

Given the current global status of English, further enhanced by information and communication technologies (ICTs), English language teachers, more than any other curriculum stakeholders, find themselves charged with

\section{How to cite this book chapter:}

Daoud, M. 2019. Language Teaching in Turbulent Times: Curriculum-Savvy Teachers for Curriculum Success and Sustainability. In: Wright, C., Harvey, L. and Simpson, J. (eds.) Voices and Practices in Applied Linguistics: Diversifying a Discipline, pp. 177-193. York: White Rose University Press. DOI: https://doi.org/10.22599/ BAAL1.k. Licence: CC BY-NC 4.0 
the responsibility of adapting their views and practices to meet the challenges of this brave new world. This chapter calls for attending to the central role of English language teachers in curriculum implementation in order to promote learner autonomy while striving to humanise the teaching learning process and to ensure curriculum success and sustainability.

If we want empowered, autonomous learners, we need empowered, autonomous teachers. These teachers need to be curriculum-savvy. They cannot perform with any degree of success without apprehending their position in the whole curriculum and understanding the constraints that shape their roles and determine their actions. If they just teach the textbook assigned to a particular level, their work remains superficial. They would simply be marking time, covering the material mechanically, with less than the desired impact on the learners' developing competence.

Teachers would gain much from being curriculum-savvy. They would have a sense of what they can and cannot do, realistically. They would know how to seek help, in terms of pedagogical and material support. They would at least be able to defend themselves in front of supervisors, learners, parents and the wider community since they - rather than the textbook writer, teacher supervisor, school principal or higher-level decision maker - are usually the only party to face criticism in the event of failure. Curriculum success is often relative, as far more curricula actually fail rather than succeed (Rodgers 1989). This is because success depends on a number of variables involving different stakeholder roles and the political, socio-economic and educational environment where English is taught.

In the MENA region, the demand for English is very strong, notably in Tunisia, Algeria and Morocco, where education is bilingual, in Arabic and French, and where foreign language proficiency, particularly in English, is an asset for higher academic and vocational achievement and better employment (British Council 2013; Daoud 2000, 2011). The current environment, especially in the wake of the 2011 political upheaval, is characterised by high turbulence, which affects language programme success.

In the first section of this chapter, I will cover different areas of turbulence with specific reference to Tunisia, where the problems are severe, often misunderstood and hardly addressed at all and the solutions complex and hard to reach or implement. In the second section, I will propose a teacher-oriented curriculum framework for teacher empowerment to help maintain the complexity and humanity of the teaching/learning process. I will conclude with some recommendations to promote curriculum success and sustainability.

\section{Areas of turbulence}

\section{Socio-economic and communication concerns}

The motto of the revolution in Tunisia in December 2010-January 2011, which initiated the Arab Spring, was Jobs, Freedom and Dignity. The fact that jobs 
came first reflected the high rate of unemployment, particularly among university graduates (nearly $40 \%$, compared with the then national average of $18 \%)$. The thinking was, and still is, that without a decent job one could not be free or lead a dignified life. Unemployment is, of course, a complex problem and the country is still struggling to deal with it, but proficiency in English is recognised by employers, policymakers and the unemployed themselves as an important factor to secure an advantage in finding a job (Daoud 1996; Champagne 2007; Erling 2015).

The importance of English has been further enhanced by the use of ICTs, not only in social media but, more importantly, in the business sector as well as in the democratic transition process supported by various foreign governments and international organisations. The last eight years have seen greater demand for English (British Council 2015) and a significant need for translation and interpreting services from/into English in practically all areas.

Another aspect of these concerns revolves around the changing communication needs brought about by ICT use in this digital age, which require us to rethink basic notions such as language, communication, and language learning and teaching. Learners communicate differently now. They have free access to information, which allows them to be autonomous - working independently from the teacher - in terms of the type and amount of information they need, the way they find it and the skills and strategies they employ to use it. If teachers do not adapt their teaching to the learners' emerging communication styles, they may very well be ignored and certainly be less effective (cp. Boss \& Krauss 2007; Motteram 2013; Nunan 1989a; Nunan 1989b; Tomlinson \& Wittaker 2013).

\section{Educational concerns}

The educational environment is highly turbulent, as there are problems at the level of policy and planning, watered-down programmes, poor assessment and evaluation, falling literacy rates and changing learner characteristics. Several studies focusing on Tunisia have consistently noted these problems in terms of general ELT and ESP programme design and implementation, and in terms of the prevailing mindset behind policymaking, planning and, consequently, funding. As far as ELT is concerned, practitioners have always had to do with ad hoc, ill-informed language-in-education policy and planning decisions (Daoud 1996, 2007, 2011; Salhi 2000). Several general English and ESP programmes have failed for a variety of reasons, including poor coordination, insufficient or discontinued funding, suspended reform initiatives and, most of all, ignorance and inertia, whereby progress is blocked or even reversed (Daoud 2000; Labassi 2010). Two particular examples, one about ELT in primary school and the other about ESP in higher education, would help illustrate this inertia and, thus, reveal the mindset prevailing among decision makers, who do not seem to consider language teaching a profession requiring advanced knowledge and high qualifications, such as accounting, engineering or medicine. 
In the 1960s and 1970s when there was a shortage of local teachers, foreigners were often hired simply because they were native speakers of English, but with scores of Tunisians graduating in English over the last 50 years, a university degree and then an additional secondary school teaching certificate (CAPES) became requirements for teaching EFL or ESP. Yet, recent reforms to introduce English in the sixth form of primary school, on a one-hour per week basis, have led to letting some primary school teachers without a degree or any proven competence in English teach the language in addition to the other subjects they had. These teachers were preferred to English degree holders, who were actually unemployed, because of 'unforeseen' administrative and logistical constraints that would have required any full-time English teacher to teach in several different schools at once. As documented by Boukadi (2013), the primary school teachers were selected based on their expressed interest and dormant competence in English as well as their presumed pedagogical expertise, which they were expected to transfer to their ELT practice. They were supposed to receive 400 hours of English instruction prior to starting teaching but only had 80 . To make matters worse, the primary school teacher's union managed to stop counselling visits by secondary school English inspectors, arguing that they were encroaching on the primary school inspectors' territory. Most recently, the Ministry of Education has announced that ELT would start in the fourth form in September 2019, taught by teachers with the same profile.

The second example about ESP illustrates a regression that has been underway since the late 1990s, when English became a compulsory subject in all academic disciplines as well as vocational training. English degree and CAPES holders have been appointed to teach the language in all specialty areas, but with no training in ESP course design, teaching and evaluation. There were initiatives, mainly funded by USAID and the British Council, to support ESP practice, but they were not sustainable, for reasons that are expounded in Daoud (2000) and Labassi (2010). Now there are well over 1,000 ESP teachers in the university and vocational training systems, but they are practically left to their own devices.

Programme goals and objectives, typically framed as a statement of an ideal in a syllabus, are weakened as they are translated into textbooks, lesson plans, classroom activities and tests. As the process goes downstream, and in the absence of systematic, professional coordination, that ideal is gradually lost since the syllabus designers, textbook writers, teacher trainers and teacherscum-test designers fail to develop a shared understanding of language, language learning and programme objectives (Daoud 2000, 2011).

New textbooks come and go every four or five years while learner-assessment procedures remain unchanged. This has led to establishing two parallel curricula: the official one, above board, costly and largely ineffective, and an unofficial one (private tutoring), which fosters test-wiseness and very little learning. Thus, new textbooks, no matter how innovative they may be, make very little 
difference in improving proficiency levels, as demonstrated by reading proficiency tests (PISA 2018).

Learner assessment, itself, is problematic because it is not reliable. It fails to adequately test what is taught and how it is taught. Tests at all levels tend to copy the format of the Baccalaureate exam (a national final high school exam that allows access to university), which reflects a predominantly structural, rather than communicative, view of language (Al-Benna 2002; Athimni 2018; Canale 1983). Programme evaluation, which should be informed by assessment outcomes, is still very much a foreign notion and, if done at all, is limited to a desk-based textbook review (Daoud 1999, 2000).

Another area of turbulence is literacy, with rates falling not only in English but also in Arabic, the national language, and French, the dominant school language (PISA 2018). Private employers often complain about the poor level of job applicant competence in all three languages (Erling 2015).

Last but not least, there is learner-related turbulence, which has to do with changing learner characteristics, with noticeable differences between student cohorts that are just two or three years apart. Communication has changed drastically thanks to ICT use, but this has made learners even more independent from the teacher. SLA research has already shown that it is difficult for teachers to ensure learning is actually happening because it is largely an internal, and often incidental and variable, process (Larsen-Freeman \& Long 1991). This poses the challenge of motivating students and the even bigger challenge of maintaining the level of motivation achieved and raising it even higher in any given lesson or a whole course within and beyond the classroom. Both learners and teachers generally recognise that there is a disconnect between language practice in the classroom and real-world language use outside in terms of content, interactional skills and strategies, as well as communication and learning modes (Chebbi 2019; Hermessi 2017).

All of the above concerns are real issues that teachers face on a daily basis, and one would hope that they are well prepared to do so. The question, then, arises as to how they can be prepared, whether they can do so by themselves and what the different stakeholders in the language curriculum can do to help them cope with the immediate demands of teaching. In the following section, I propose a teacher-oriented framework for curriculum development and implementation to take into account the complexity of the teaching/learning process and to promote humanising ELT.

\section{A teacher-oriented curriculum framework for humanising ELT}

Essentially, there are two approaches to curriculum development and implementation: top-down and bottom-up. Both have direct implications for teachers and determine, to a large degree, how empowered they may or may not 
be while doing their day-to-day work. The two approaches seem dichotomous, involving sets of definite roles for different stakeholders with little overlap or cooperation in the top-down approach, on the one hand, and, on the other, a range of possibilities for participation, interaction and co-construction in the bottom-up approach (cp. Johnson 1989; Nation and Macalister 2010). However, for teachers who find themselves with a predetermined textbook and learnerassessment system, it is advisable to understand their programme environment and try to adapt in order to be more effective and achieve some degree of job satisfaction.

\section{Top-down vs. bottom-up curriculum development and implementation}

Before embarking on the presentation of the framework, note that the higherorder labels used in Figures 8 and 9 below are borrowed from Johnson (1989), along with the idea that curriculum development is a process involving decision-making by all the stakeholders at all levels. Whatever the case, the teachers are the ones who actually implement the curriculum in the classroom. In a top-down curriculum, as schematically illustrated in Figure 8, teachers are confined to the inner circle (classroom implementation, or CI). They are tasked with teaching particular materials - usually a set textbook - and testing their students' achievement according to a pre-established system. They would perform these tasks without any contact with other programme stakeholders, except for an occasional encounter with their inspector-cum-trainer. English inspectors in Tunisia actually also serve as teacher trainers, syllabus and textbook writers, and test designers, as will be seen next.

Novice teachers undergo two years of in-service training under the coaching/ supervision of their district inspector. In the first year, they attend a series of 'model lessons' taught by experienced teachers in the presence of the inspector/ trainer, then discuss them and keep a training portfolio, which the inspector eventually evaluates. Meanwhile, the inspector observes them twice in their own classrooms. In the second year, the inspector visits them twice more to evaluate their teaching and supervises their completion of a trainee research report (an action research project), after which he confirms them in their position (Saidi 2012). Once tenured, teachers may go on teaching for years without a visit from their district inspector, or participation in a training workshop or professional conference. There is no requirement for teachers of the same level in the same school to coordinate lesson planning, teaching and progress tests. There is, however, one requirement for them to co-design the final quarterly exam. Then, they individually calculate their students' cumulative averages for the quarter and the whole year and turn them in.

Thus, teachers may remain within the confines of the inner circle (CI), teaching and testing the level(s) they choose or are assigned with little sense of the broader philosophy of the programme and its goals and objectives, and little 


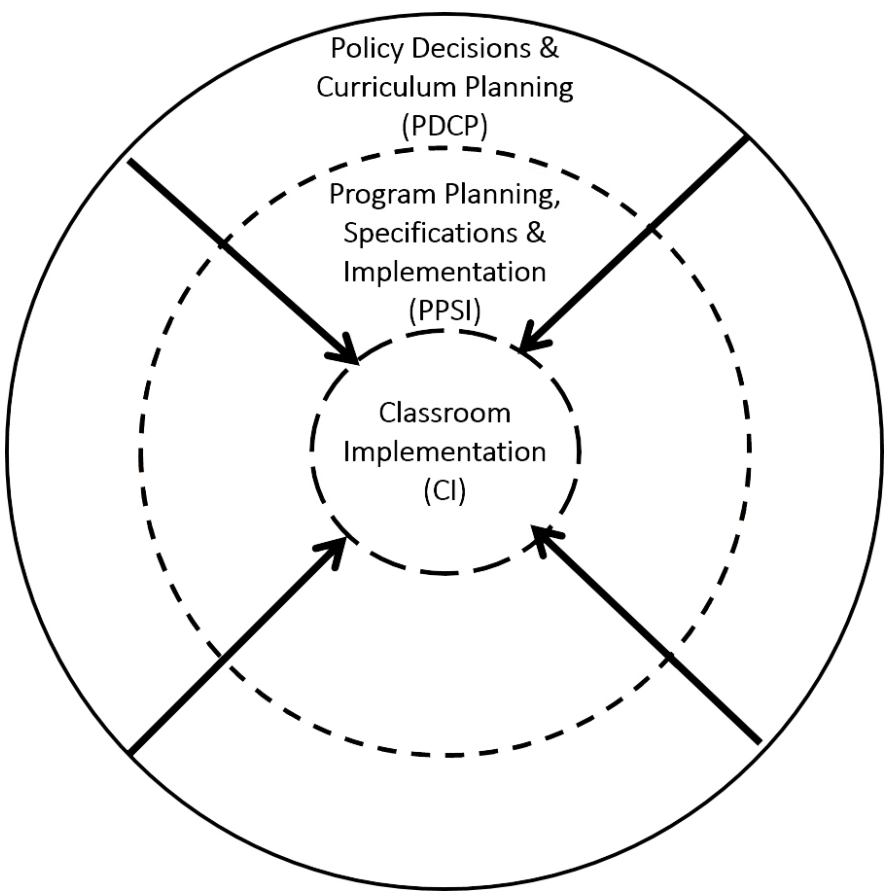

Figure 8: Top-down curriculum design and implementation (Copyright Mohamed Daoud, CC BY-NC 4.0).

incentive to innovate, coordinate with colleagues or reach out to the outer circles (program planning, specifications and implementation, PPSI, and policy decisions and curriculum planning, PDCP). All the teachers are required to have a copy of the official syllabus, but there is no evidence that they refer to it or fully apprehend it. There is a teacher's manual to go with each textbook, but it is used more as an answer key than a tool to promote teacher flexibility in practice. In fact, teachers tend to keep the same level(s) year after year, further depriving themselves of the opportunity to experience the programme sequence, prior to and beyond the level they teach, let alone the broader dimensions of PPSI and PDCP.

In this top-down structure, PDCP involves policy decisions, which are obviously made at the highest (presidential/ministerial) level on the basis of perceived political, economic and educational priorities, usually with some input from academic or pseudo-professional government counsellors. The next stage, PPSI, includes work at the level of syllabus design and textbook writing and usually involves an academic ELT specialist and a group of secondary school inspectors. These inspectors typically end up sharing the writing of the textbooks and teacher guides by level in teams comprising two or three teachers 
that they personally select for the task. Then, these materials go to an academic (who may be an English literature or culture studies, rather than an ELT specialist) for validation based on a desk-based review. Finally, the textbooks reach the classroom, where teachers proceed with CI, as explained above.

A reasonable alternative to this top-down approach, which is inherently constraining to the teacher, would be a bottom-up approach, as shown in Figure 9. This approach may be envisaged as a situation where teachers are managing their job with all its complexity while always trying to reach out beyond the classroom, to the broader dimensions of the curriculum. They would do so in order to (a) make sense of the whole curriculum, (b) position themselves as adequately as possible to be more effective and (c) identify stakeholders that make them more empowered and less vulnerable. The alternative, then, is a teacher-oriented framework for curriculum development and implementation, where CI, PPSI and PDCP interconnect to allow teachers to develop a personal sense of ownership of the curriculum as a deliberative process, be more enterprising and autonomous and potentially defend themselves when faced with criticism or failure.

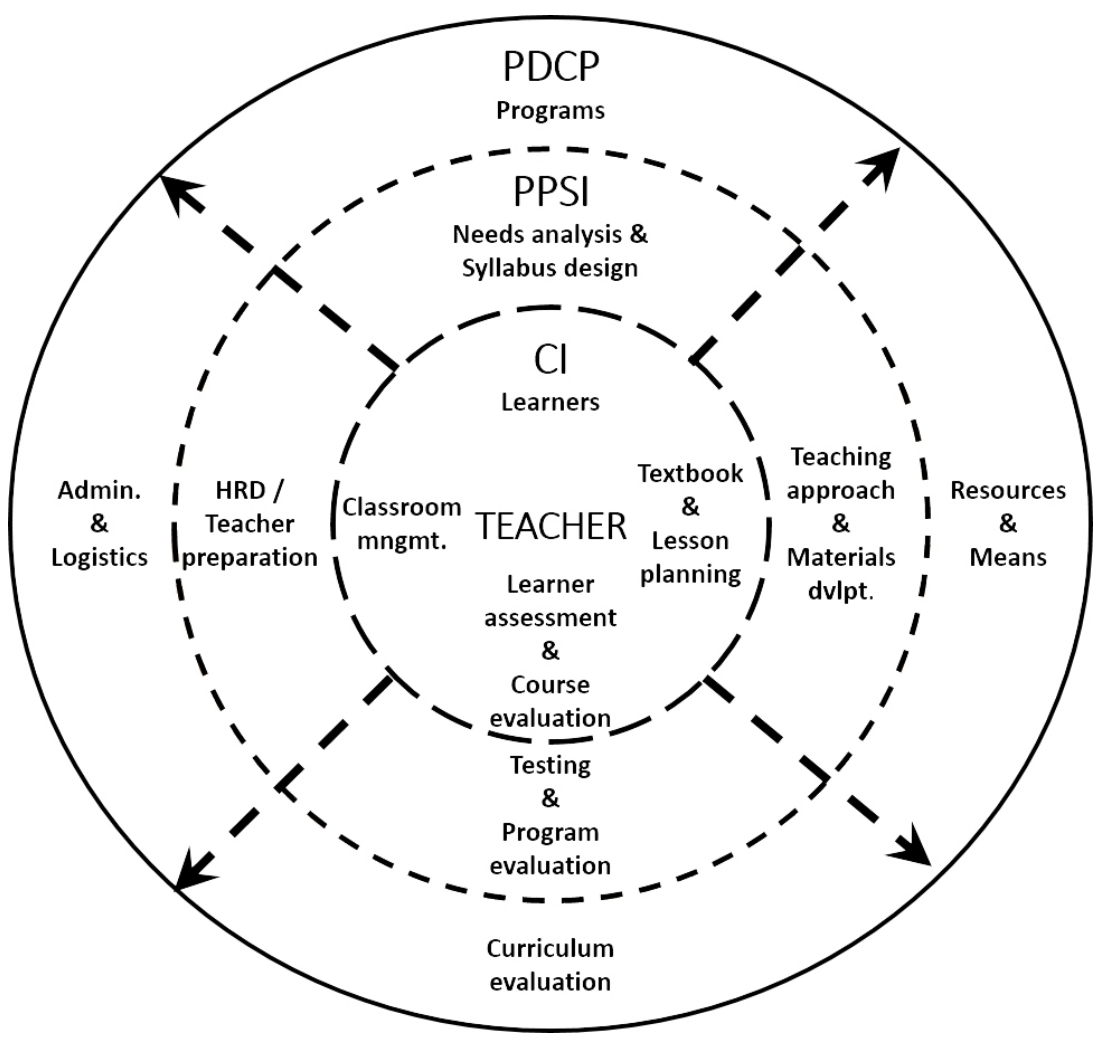

Figure 9: A teacher-oriented framework for curriculum development and implementation (Copyright Mohamed Daoud, CC BY-NC 4.0). 
Let us consider the teachers' roles and possible behaviour in more detail within this bottom-up framework, bearing in mind that it does not constitute another swing of the pendulum from learner-centredness, which has been in vogue since the 1980s with the rise of communicative language teaching, back to teacher-centredness, as was the case in traditional, teacher-fronted classrooms. It is rather an attempt to make the point that only an empowered, autonomous, curriculum-savvy teacher can implement a true learner-centred curriculum (cp. Benson 2013; Johnson 1989; Lamb \& Reinders 2008).

At the CI level, teachers obviously deal with learners as the key stakeholders in the curriculum. To promote learning, they use materials/a textbook and rely on lesson planning. Teaching the textbook without careful lesson planning, as is often the case in a top-down curriculum, as described above, is not beneficial to the learners, even when a teacher's guide is available. Judicious lesson planning not only ensures coverage of the lesson/course objectives as specified in the syllabus but also serves two additional purposes: (a) it guarantees that learner assessment adheres to the same objectives, and (b) it helps to amass data for course evaluation. Finally, teachers can achieve CI through effective classroom management, including good time distribution, task sequencing, organising student interaction and dealing with contingencies.

It could be argued that asking teachers to do more than the above is unreasonable, or too ambitious, for classes run as such would surely promote learning and enhance programme success. However, it takes a special kind of teacher to achieve this much and, more importantly, sustain this effort. It takes a teacher who strives to reach beyond CI to the PPSI level. To properly serve learners, teachers need to understand their needs as translated into the syllabus. To properly use the textbook and plan their lessons, they need to understand the teaching approach proposed in the syllabus and how the teaching materials were designed. There are teachers, textbook authors and even inspectors-cumtrainers who are still struggling with notions such as a communicative task, reading strategy development or process writing, let alone teaching them properly.

Likewise, for teachers to properly assess learners and evaluate their own teaching, they need to go beyond CI in order to understand how to design reliable tests that stem from the course objectives and appreciate the value of course evaluation and how much it contributes to programme evaluation at the PPSI level. It should be noted that testing is probably the weakest link in our system, as very few teachers graduate with any testing knowledge to begin with. As stated earlier, testing is plagued by adhering to a set format of the Baccalaureate exam, while programme evaluation is hardly done. Since the system is deficient at this level, conscientious teachers would have to take it upon themselves to develop the awareness and expertise required to do their job and never miss an opportunity to encourage programme evaluation as a means to improve programme implementation.

As regards classroom management and overall CI performance, teachers need to understand how human resource development (HRD) and teacher preparation are provided at the PPSI level and seek opportunities for further 
self-development. Rather than waiting for training to come their way, they should strive to participate in training activities organised by inspectors for novice teachers and by teacher associations. They can also read about ELT research and practice from the wealth of resources available online.

It is much easier nowadays for teachers, in Tunisia and elsewhere in the MENA region, to extend their interest to the PPSI level of the curriculum given a number of positive developments, including the emergence of professional associations, academic degree programmes and presentation and publication fora. Indeed, several national and regional teacher associations, some of which are affiliated with international associations such as IATEFL and TESOL (e.g., TESOL Arabia in the Gulf, MATE in Morocco, Tunisia TESOL and Africa TESOL) are active. Many universities have established MA and/or PhD programmes in applied linguistics or teacher education, thus producing qualified practitioners who are not only teaching but also conducting valuable empirical research in localised contexts. Such research is being shared in local and regional conferences, along with the best practices stemming from classroom applications, and disseminated more broadly in mainstream academic journals, and more commonly in online publications. Last but not least, there is a multitude of dedicated websites, social media channels/pages and smartphone applications which facilitate access to information and encourage creativity, innovation and discussion. These developments have created a new dynamic that is promoting emulation, a wider exchange of ideas and experiences and a keener sense of empowerment.

Teachers may benefit even more by opening up to the broader level of PDCP in the framework proposed in order to understand the nature of the language programme to which they are contributing significantly in the classroom. For instance, teachers would find it helpful to understand the policy decisions to teach English for so many hours a week at particular levels and across disciplines. They would better gauge their learners' needs in the socio-economic context of the curriculum and, eventually, participate in developing an advocacy agenda for teachers' associations and unions to call for the allocation of adequate human and material resources to provide better materials and teacher training as well as consequential evaluation and, thus, ensure curriculum success and sustainability. The post-revolution environment in Tunisia, which has culminated in setting legal provisions for open access to information, good governance and accountability, should promote teacher engagement in the curriculum at the PDCP level on an individual or institutional level.

\section{Potential obstacles to promoting the bottom-up curriculum}

The most obvious obstacles include policy considerations and common misconceptions about ELT. Experience around the world has shown that governments are not forthcoming with adequate resources for language teaching. The 
prospects for funding ELT in the MENA region, particularly in the poorer countries, are not so bright, given the belief still held by decision makers that the British and the Americans would strive to promote their language and, therefore, provide aid to do so (Daoud 2000). Policymakers do not seem fully cognisant of the importance of English as an international language, which the inner-circle countries, to use Kachru's terminology (Kachru 2006), consider a valuable commodity. Public opinion in Tunisia, which is in the expanding circle, has clearly shifted in favour of learning English and even developing some ownership (Widdowson 2003) of it; however, policymakers seem unable or unwilling to sideline French, which was adopted after independence as an adjuvant language for the sake of economic development and cultural modernisation (Daoud 2011).

The private sector is not helping as much as it should to promote English either. Private companies, which complain about the low proficiency level of job applicants, are doing very little in this regard (Erling 2015). Local and foreign private institutions teaching English, including universities, seem more interested in increasing their profit margin than contributing in any tangible way to ELT development, in terms of research, policy and planning, programme design or practice. Except for a few institutions that employ mostly permanent staff, the majority hire part-time teachers from the public sector who also bring the official syllabi and tests.

The other obstacle to implementing the bottom-up approach involves misconceptions commonly held by textbook authors, inspectors and teachers about language, language learning, programme/course objectives, learnercentredness and language teaching. In spite of professing the communicative approach, these stakeholders mostly fall short of teaching language as/for communication. Teaching and testing are still driven by a structural view of language, with a greater focus on correctness as opposed to appropriateness and fluency, as well as a behaviourist/cognitive view of language learning, giving little attention to affect, motivation and authentic language use in realistic situations. This situation is further undermined by private tutoring, which promotes learning word lists through translation and grammar through sentence analysis and practice. As for skill development, oral/written text comprehension mostly involves answering copy-and-paste question types, with little focus on critical thinking and synthesising, while speaking and composition are product, rather than process-based (Ellili Cherif 2002; Saidi 2012; Seddik 2017).

This reflects additional misconceptions about programme/course objectives, learner-centredness and language teaching. Lessons generally involve more testing than actual teaching, where teachers and learners focus on finding correct answers, as opposed to taking the time to explore options to communicate successfully and promote learner awareness, critical thinking, autonomy, cooperation and creativity. Teachers often complain about the lack of time to cover the whole textbook, which indicates a greater concern about the quantity, rather quality, of teaching, and about large class sizes, which reveals a misunderstanding 
of individualised instruction and how to engage learners in meaningful tasks through individual, pair or group work.

\section{The scope of language teaching and learning}

To overcome these obstacles and correct these misconceptions, it is important for teachers to apprehend the full scope of language teaching and learning (see Figure 10, below). Teaching English with a predominantly structural view of language limits the scope to practising grammar and vocabulary at the superficial level (illustrated by the inner circle). Even when the matrix is a text (oral, written, multimodal or multimedia, as shown in the second circle), the

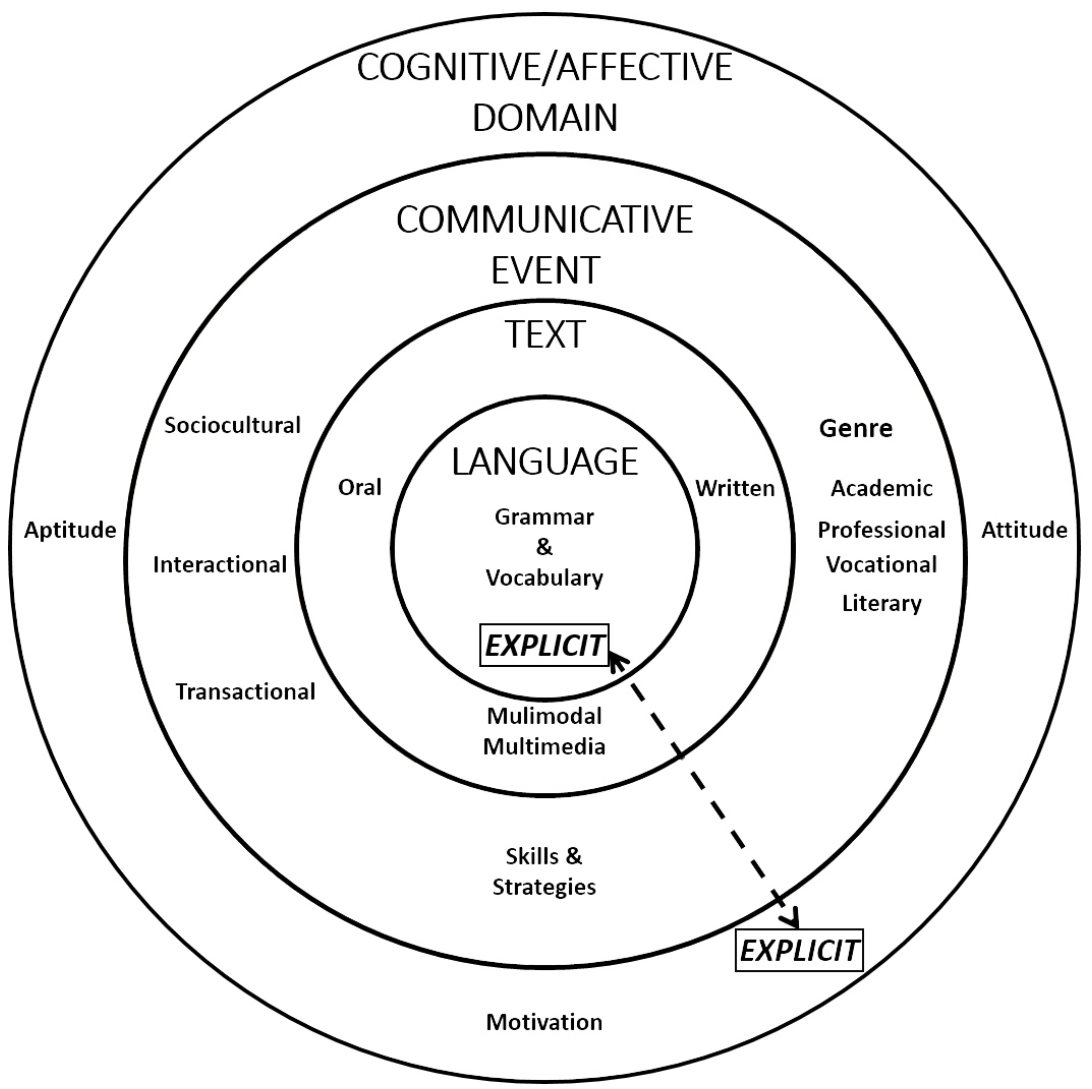

Figure 10: The scope of English language teaching and learning (Copyright Mohamed Daoud, CC BY-NC 4.0). 
comprehension questions seldom lead to realistic interaction. The class may engage in skill and sub-skill practice, such as skimming for the main idea and guessing the meaning of unfamiliar words, but the text is used mainly as a linguistic object (TALO), rather than a vehicle for information (TAVI), and, eventually, a model for writing, rather than a springboard for production (TASP) (Johns \& Davies 1983).

However, when the text is treated as a communicative event, it becomes an instance of authentic interaction, which allows for simulating a real-life situation. It, thus, requires recreating a sociocultural context and illustrates an interactional or a transactional discourse genre (academic, professional, vocational or literary) and lets learners engage in it in terms of specific roles and a particular purpose in a given context. Only then would they deploy the relevant skills and sub-skills and the appropriate strategies to read or listen and interact, as required by the situation at hand. But, for communication to be truly authentic, learners would have to engage in the text at an even higher level, in the cognitive/affective domain, which involves their aptitude, attitude and motivation.

The challenge for teachers would be to keep in mind the full scope of language teaching and learning. Note that the structural aspects of language are the most explicit (or tangible), since they are laid out in the textbook and more readily instantiated in the mind, while the cognitive/affective aspects of communication are the most implicit (or hidden) and are, thus, harder to instantiate. The success of the teaching/learning process would depend on reaching more often for the implicit aspects and then balancing both, through a regular process of focusing and defocusing, as determined by the complexity of the course and the learners' progress.

\section{Humanising ELT}

This approach can be very helpful to teachers because it integrates all aspects of authentic communication (Nunan 2004; Widdowson 1979). It is true that when we teach language we tend to do it in bits and pieces (forms, meanings, skills, genres etc.), but to approximate real communication we should strive to provide learners with opportunities to experience language as whole persons, at the cognitive, affective and sociocultural/interactional levels. In other words, we should help them to engage in learning as complex human beings, with their minds, hearts and relationships.

It is possible to humanise teaching at the levels of course and lesson planning, discussing lesson objectives in class, managing classroom tasks and, of course, assessing learners. This can be done through realistic, meaningful activities that simulate real-life situations in social or work contexts. The measure of success in this endeavour would be the learners' cognitive, affective and interactional engagement in the activities. 


\section{Conclusions and recommendations}

This chapter has sought to consolidate the role of English teachers to promote ELT in the MENA region, with a specific focus on Tunisia, at a time when the demand for this language keeps growing in a socio-economic environment characterised by high turbulence in the wake of the Arab Spring. It proposed a teacher-oriented, bottom-up approach to curriculum development and implementation in order to empower teachers so that they can, in turn, empower the learners and, thus, promote curriculum success and sustainability.

In light of the above arguments, it is important for all curriculum stakeholders to view language teaching as a true profession and to nurture the humanity of both teachers and learners as complex, evolving human beings in order to prepare the learners for effective communication in the real world. It is also important to keep in mind that teachers do not teach (for language teaching is not about knowledge transfer); instead, they provide contexts for learners to learn and learn how to learn, thus promoting learner autonomy and creativity.

As key stakeholders in curriculum implementation in the classroom, language teachers are, by and large, left to their own devices. As they are called upon to be effective and innovative, they should to be careful not to be overburdened or disillusioned. To do so, they need to do the following:

- Keep in mind the big picture of the curriculum as well as the scope of language teaching and learning, as illustrated in Figures 9 and 10, above.

- Stay on their toes as professionals at the individual level, through selfdevelopment.

- Organise themselves professionally to exchange ideas and best practices and to develop advocacy agendas through teachers' associations.

- See themselves as agents of change in order to ensure curriculum renewal and sustainability.

- Actively seek the support of the educational system, in terms of access to resources as well as having a voice in curriculum policy and planning.

Finally, it is incumbent upon applied linguists, perhaps more than any other curriculum stakeholder, to support the teachers, for who else can support them better than applied linguists? We need to

- Actually do applied linguistics, by working closely with teachers to help them meet the complex challenges of classroom implementation. We have the knowledge and expertise to offer adequate support and, unlike inspectors, we do not have the administrative authority which teachers may find threatening.

- Adapt our thinking and methods to address the teachers' professional concerns. Different teaching situations, teacher profiles and attitudes as well as changing learner needs will require us to develop pragmatic disciplinarity 
(cp. Widdowson, this volume); that is, we need to be pragmatic (to solve real-world, language-related problems) while adhering to disciplinary rigour in terms of concepts and research methods.

- Influence curriculum policy and planning through direct involvement and academic pressure, as well as better lobbying/marketing skills in order to reach policymakers and the public at large.

\section{References}

Al-Benna, S. 2002 The validity of the Baccalaureate English exams for the science and arts sections 1998, 1999. Unpublished MA thesis, Institut Supérieur des Langues de Tunis.

Athimni, A. 2018 Investigating writing literacy in Tunisia: The case of EFL university writing teachers. In Ahmed, A. and Abouabdelkader, H. (eds), Assessing EFL writing in the $21^{\text {st }}$ century Arab World. Cham: Palgrave Macmillan. pp. 163-189. DOI: https://doi.org/10.1007/978-3-319-64104-1_7

Benson, P. 2013 Teaching and researching autonomy. Abingdon, Oxon and New York: Routledge.

Boss, S. and Krauss, J. 2007 Reinventing project-based learning. Washington, DC: International Society for Technology in Education (ISTE).

Boukadi, S. 2013 Teachers' perceptions about the future of English language teaching and learning in Tunisia after the 2011 revolution. Unpublished $\mathrm{PhD}$ thesis, University of Exeter.

British Council 2013 Perspectives on English in the Middle East and North Africa. London: British Council.

British Council 2015 Tunisia speaks English. Available at https://www.britishcouncil. tn/en/tunisia-speaks-english [Last accessed 23 September 2018].

Canale, M. 1983 From communicative competence to communicative pedagogy. In Richards, J.C. and Schmidt, R.W. (eds), Language and communication. London: Longman. pp. 3-27.

Champagne, J. 2007 'Job seekers' and 'enterprise incubators': Educational reform in Tunisia. Changing English, 14(2): 201-215.

Chebbi, O. 2019 The relationship between teacher job-related aspects, teacher job satisfaction and their occupational commitment. Unpublished MA thesis, Institut Supérieur des Langues de Tunis.

Daoud, M. 1996 English language development in Tunisia. TESOL Quarterly, 30(3): 598-605.

Daoud, M. 1999 The management of innovation in ELT in Tunisia. In Jabeur, M., Manai, A. and Bahloul, M. (eds), English in North Africa. Tunis: TSAS Innovation Series, TSAS and the British Council. pp. 121-137.

Daoud, M. 2000 LSP in North Africa: Status, problems, and challenges. In Grabe, W. (ed.), Annual review of applied linguistics, 20: Applied linguistics as an emerging discipline. New York: Cambridge University Press. pp. 77-96. 
Daoud, M. 2007 The language situation in Tunisia. In Kaplan, R.B. and Baldauf Jr., R.B. (eds), Language planning and policy in Africa, 2: Algeria, Cote d'Ivoire, Nigeria and Tunisia. Clevedon: Multilingual Matters. pp. 256-307.

Daoud, M. 2011 The sociolinguistic situation in Tunisia: Language rivalry or accommodation? International Journal of the Sociology of Language, 211: 9-33.

Ellili Cherif, M. 2002 Evaluation of the communicative approach in English language teaching in Tunisian secondary schools. Unpublished $\mathrm{PhD}$ thesis, Institut Supérieur des Langues de Tunis.

Erling, E. 2015 The Relationship between English and employability in the Middle East and North Africa. Manchester: British Council.

Hermessi, T. 2017 Teacher perception of cultural difference in L2 materials: Is filtering culture the right approach?. The Electronic Journal for English as a Second Language, 21(2): 1-19. Available at: https://eric.ed.gov/?q=Tarek+ Hermessi\&ft=on [Last accessed 15 January 2019].

Johns, T. and Davies, F. 1983 Text as a vehicle for information: The classroom use of written texts in teaching reading in a foreign language. Reading in a Foreign Language, 1(1): 1-19.

Johnson, R.K. (ed.) 1989 The second language curriculum. Cambridge: Cambridge University Press.

Kachru, B. 2006 Standards, codification and sociolinguistic realism: The English language in the outer circle. In Bolton, K. and Kachru, B. (eds), World Englishes: Critical concepts in linguistics, 3. Abingdon, Oxon: Routledge. pp. 241-269.

Labassi, T. 2010 Two ESP projects under the test of time: The case of Brazil and Tunisia. English for Specific Purposes, 29(1): 19-29.

Lamb, T. and Reinders, H. 2008 Learner and teacher autonomy: Concepts, realities, and responses. Amsterdam: John Benjamins.

Larsen-Freeman, D. and Long, M.H. 1991 An introduction to second language acquisition research. New York: Longman.

Motteram, G. (ed.) 2013 Innovations in learning technologies for English Language Teaching. London: British Council.

Nation, I.S.P. and Macalister, J. 2010 Language curriculum design. New York: Taylor and Francis.

Nunan, D. 1989a Hidden agendas: The role of the learner in program implementation. In Johnson, R.K. (ed.), The second language curriculum. Cambridge: Cambridge University Press. pp. 176-186.

Nunan, D. 1989b Designing tasks for the communicative classroom. New York: Cambridge University Press.

Nunan, D. 2004 Task-based language teaching. New York: Cambridge University Press.

PISA 2018 PISA 2015 results in focus. The Organisation for Economic Co-operation and Development (OECD). Available at https://www.oecd.org/pisa/pisa2015-results-in-focus.pdf [Last accessed 8 October 2018]. 
Rodgers, T.S. 1989 Syllabus design, curriculum development and polity determination. In Johnson, R.K. (ed.), The second language curriculum. Cambridge: Cambridge University Press. pp. 24-34.

Saidi, E. 2012 Evaluation of EFL teachers' pre- and in-service training: Exploring the form and content of teacher development and its impact on classroom practice. Unpublished PhD thesis, Institut Supérieur des Langues de Tunis.

Salhi, R. 2000 Language shift: The linguistic situation in Tunisia, revisited. In Les langues en Tunisie: Etat des lieux et perspectives. Tunis: Centre des Publications Universitaires. pp. 31-42.

Seddik, A. 2017 Evaluation of the curricula in the English language departments in Tunisian higher education institutions. Unpublished $\mathrm{PhD}$ thesis, Institut Supérieur des Langues de Tunis.

Tomlinson, B. and Whittaker, C. (eds) 2013 Blended learning in English language teaching: Course design and implementation. London: British Council.

Widdowson, H.G. 1979 Teaching English as communication. Oxford: Oxford University Press.

Widdowson, H.G. 2003 Defining issues in English language teaching. Oxford: Oxford University Press. 